\title{
Recurrent ATP1A2 mutations in Portuguese families with familial hemiplegic migraine
}

\author{
Maria-José Castro · Anine H. Stam · Carolina Lemos · José Barros · Raquel G. Gouveia • \\ Isabel Pavão Martins · Jan B. Koenderink · Kaate R. J. Vanmolkot · Alexandre P. Mendes · \\ Rune R. Frants · Michel D. Ferrari · Jorge Sequeiros · José M. Pereira-Monteiro • \\ Arn M. J. M. van den Maagdenberg
}

Received: 13 June 2007 / Accepted: 27 September 2007/Published online: 19 October 2007

(C) The Japan Society of Human Genetics and Springer 2007

\begin{abstract}
Familial hemiplegic migraine is a rare autosomal dominant subtype of migraine with aura. Three genes have been identified, all involved in ion transport. There is considerable clinical variation associated with FHM mutations. Genotype-phenotype correlation studies are needed, but are challenging mainly because the number of carriers of individual mutations is low. One exception is the recurrent $\mathrm{T} 666 \mathrm{M}$ mutation in the FHM1 CACNA1A gene that was identified in almost one-third of FHM families and showed variable associated clinical features and severity, both within and among FHM families. Similar studies in the FHM2 ATP1A2 gene have not been performed because of the low number of carriers with individual mutations. Here we report on the recurrence of ATP1A2 mutations M731T and T376M that affect sodiumpotassium pump functioning in two Portuguese FHM families. Considerably increasing the number of mutation carriers with these mutations indicated a clear genotypephenotype correlation: both mutations are associated with
\end{abstract}

M.-J. Castro · C. Lemos - J. Sequeiros .

J. M. Pereira-Monteiro

Instituto de Ciências Biomédicas Abel Salazar,

Universidade do Porto, Porto, Portugal

M.-J. Castro · C. Lemos · J. Sequeiros

UnIGENe, IBMC - Instituto Biologia Molecular Celular,

Universidade do Porto, Porto, Portugal

A. H. Stam - M. D. Ferrari - A. M. J. M. van den Maagdenberg Department of Neurology, Leiden University Medical Center, Leiden, The Netherlands

J. Barros - J. M. Pereira-Monteiro ( $₫)$

Serviço de Neurologia, Hospital Geral de Santo António (HGSA), Largo Abel Salazar, 4099-001 Porto, Portugal

e-mail: permonteiro@mail.telepac.pt pure FHM. In addition, we show that recurrent mutations for ATP1A2 are more frequent than previously thought, which has implications for genotype-phenotype correlations and genetic testing.

Keywords Cell survival assay - FHM2 . Genotype-phenotype correlations - Recurrent mutations . $\mathrm{Na}^{+}, \mathrm{K}^{+}$-ATPase

\section{Introduction}

Familial hemiplegic migraine (FHM) is a rare autosomal dominantly inherited subtype of migraine with aura (MA), in which attacks are accompanied by the presence of motor weakness during the aura phase that is followed by headache (ICHD-II 2004). FHM is a genetically heterogeneous disorder and three genes have been identified thus far. The FHM1 gene, CACNA1A, located on chromosome 19p13,

R. G. Gouveia - I. P. Martins

Instituto de Medicina Molecular (IMM),

Lisbon Faculty of Medicine, Lisboa, Portugal

J. B. Koenderink

Department of Pharmacology and Toxicology,

Nijmegen, University Medical Centre St Radboud,

Nijmegen, The Netherlands

K. R. J. Vanmolkot · R. R. Frants .

A. M. J. M. van den Maagdenberg

Department of Human Genetics, Leiden University Medical

Center, Leiden, The Netherlands

A. P. Mendes

Serviço de Neurologia, Centro Hospitalar do Nordeste,

Mirandela, Portugal 
encodes the pore-forming $\mathrm{Ca}_{\mathrm{v}} 2.1-\alpha 1$ subunit of neuronal voltage-gated $\mathrm{Ca}_{\mathrm{v}} 2.1$ (P/Q-type) $\mathrm{Ca}^{2+}$ channels. Mutations in CACNAIA cause a broad clinical spectrum of FHM and associated features such as ataxia, recurrent coma, or absence or generalized epilepsy (Ophoff et al. 1996; Ducros et al. 2001; Jouvenceau et al. 2001). The FHM2 gene, ATP1A2, on chromosome 1q21-23 (FHM2) (Ducros et al. 1997) encodes the $\alpha 2$ subunit of $\mathrm{Na}^{+}, \mathrm{K}^{+}$-ATPases, and is involved in ion transport across the plasma membrane. Mutations in the ATP1A2 gene are associated with pure FHM (De Fusco et al. 2003; Vanmolkot et al. 2003; Jurkat-Rott et al. 2004; Kaunisto et al. 2004; Riant et al. 2005; Pierelli et al. 2006) and in rare cases, cerebellar problems (Spadaro et al. 2004), benign familial infantile convulsions (BFIC) (Vanmolkot et al. 2003), alternating hemiplegia of childhood (AHC) (Bassi et al. 2004; Swoboda et al. 2004), severe episodic neurological deficits and permanent mental retardation (Vanmolkot et al. 2006) or basilar migraine (Ambrosini et al. 2005). Recently, a third FHM gene, SCN1A, located on chromosome 2q24, encoding the pore-forming subunit of voltage-gated $\mathrm{Na}_{\mathrm{v}} 1.1$ sodium channels, was identified in three German FHM families that share a common ancestry (Dichgans et al. 2005).

Straightforward genotype-phenotype correlation studies for FHM are difficult, because of the clinical variation and low number of mutation carriers. However, for certain FHM mutations that are found more frequently, especially the FHM1 mutation T666M, which was reported in about one-third of hemiplegic migraine probands, such detailed studies could be performed (Ducros et al. 2001). T666M mutations were identified on many different haplotypes, indicating they occurred as independent mutational events. For instance, Ducros and colleagues reported nine families and one isolated case that showed eight different genetic backgrounds (Ducros et al. 1999). Interestingly, there is considerable phenotypic variation described with the T666M mutation, ranging from persons with non-hemiparetic migraine episodes, pure hemiplegic migraine, and patients with associated permanent cerebellar ataxia (Ophoff et al. 1996; Ducros et al. 1999; Friend et al. 1999; Ducros et al. 2001; Terwindt et al. 2002; Kors et al. 2003). A second recurrent FHM1 mutation R583Q was mostly reported in patients suffering from FHM and associated ataxia (Battistini et al. 1999; Ducros et al. 2001; Alonso et al. 2003). A homogeneous clinical phenotype also seems apparent for FHM3 mutation Q1489K as all 15 mutation carriers had pure FHM, although three mutation carriers reported benign epileptic seizures during infancy (Dichgans et al. 2005).

However, meaningful genotype-phenotype studies in ATP1A2 have not been possible, due to the lack of sufficient carriers for individual mutations. The main reason is that almost all ATP1A2 mutations are unique to a particular FHM2 family. Few exceptions with a very small number of mutation carriers have been reported (Jurkat-Rott et al. 2004; Riant et al. 2005). Here, we describe the recurrence of two ATP1A2 mutations in two Portuguese FHM families without ataxia or epilepsy and, for the first time, were able to perform genotype-correlation studies for ATP1A2 on a large number carriers with specific mutations. Our findings clearly show that recurrence of ATP1A2 mutations is more frequent than described until now. This not only implies that such mutations should, perhaps, be screened with priority in genetic screening, but that identification of additional mutation carriers will also facilitate meaningful genotype-phenotype correlations.

\section{Materials and methods}

\section{Clinical description}

Two Portuguese families were interviewed and the clinical diagnosis was established according to the criteria of the International Headache Society (IHS) as mentioned in the 2004 revision of the International Classification of Headache Disorders (ICHD-II 2004). A panel of 176 blood donors with no headache history from the Hospital Geral de Santo António (HGSA) was selected as a control group. All participant subjects gave their informed consent for this study. The HGSA ethics committee approved this study.

\section{Family 1}

Six of the FHM patients (I:2, II:3, II:5, II:6, III:1 and III:2) from this family (Fig. 1a) had typical hemiplegic migraine attacks, in many cases precipitated by head trauma (details on clinical features of patients with a gene mutation are listed in Table 1a). The onset of these attacks ranged from 9 to 16 years old, and attack frequency varied from less than one (i.e. II:3) to six per year. Auras in some cases were prolonged, and started with visual and sensitive symptoms that preceded motor disturbances and dysphasia. In some cases the duration of the headaches was shorter than $4 \mathrm{~h}$. Visual hallucinations and neuropsychological aura were reported by patient II:3. Neurological evaluation in FHM patients was normal, except for patient III:1 that showed minor cerebellar dysarthria. Interictal neurological examination revealed no nystagmus. At the initial examination, an MRI was made that revealed "unspecific periventricular white matter lesions" (data not available). Unfortunately, patients II:3, III:1 and III:2 refused genetic testing. Although very likely, it remains (somewhat) unclear whether these additional patients have the same gene mutation as identified 


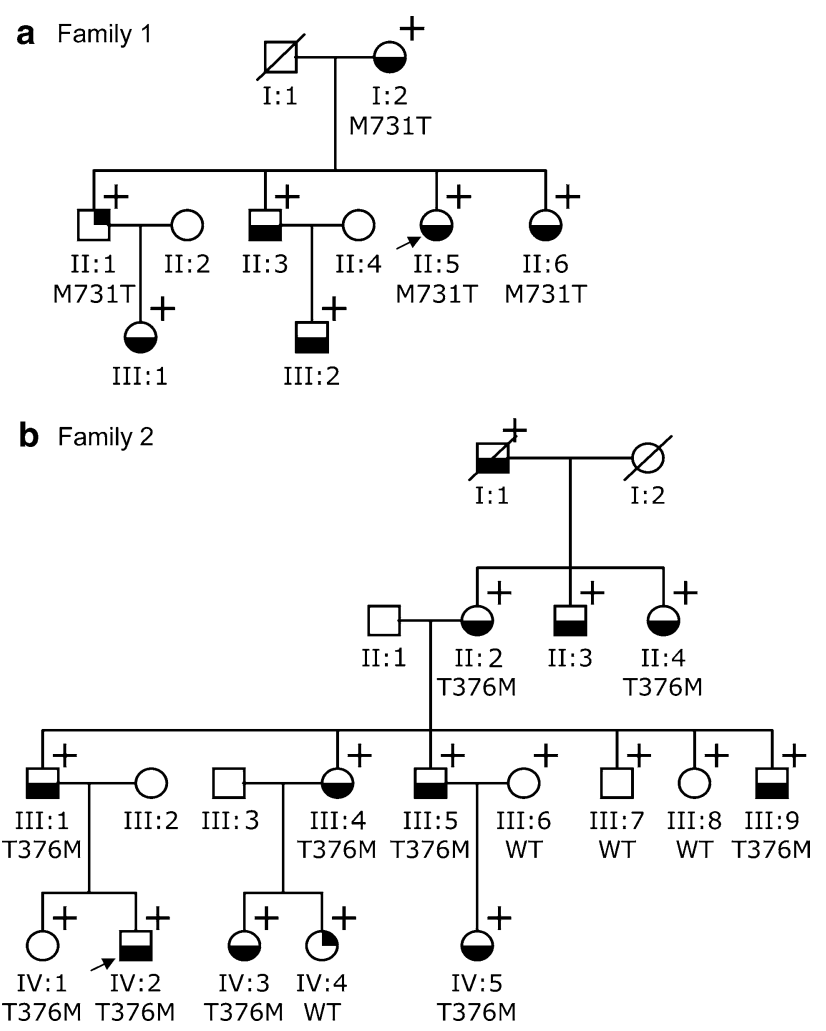

Fig. 1 Pedigrees of Portuguese FHM families 1 (a) and 2 (b). Clinical diagnosis is represented by different symbols: black lower half symbols indicate individuals with hemiplegic migraine; black upper right squares represent migraine with aura. Arrows indicate probands. Plus signs indicate individuals that were clinically evaluated. Heterozygous mutation carriers are indicated M731T or T376M. Tested non-mutation carriers are indicated WT (wild-type)

in the other hemiplegic migraine patients in this family. No history of ataxia, seizures, or abnormalities in mental or physical development was reported.

\section{Family 2}

In this four-generation family, eleven individuals affected by pure hemiplegic migraine were clinically evaluated (Fig. 1 b) (details of the clinical features of patients with a gene mutation are listed in Table 1b). Patients I:1, II:2, II:3, II:4, III:1, III:4, III:5, III:9; IV:2, IV:3, and IV:5 all suffered from attacks of hemiplegic migraine, with a frequency ranging from four in total to once a month. Attacks were associated with visual and/or sensory aura symptoms, hemiparesis and speech disturbances (varying in duration between $10 \mathrm{~min}$ and $10 \mathrm{~h}$ ). Patient IV:2 had one atypical attack lasting 1 week, during which he had generalized slowing over the left hemisphere, on EEG, and normal brain MRI. Interictal EEG was normal. Of note, all four attacks of hemiplegic aura in patient II:2 were not associated with headache. Ataxia or epilepsy was not reported for any of the affected family members. Except for patient III:9 who showed abnormal aggressive behavior (not further specified episodes of aggressive and inappropriate or dangerous behavior after minor frustration) and "some learning difficulties", all affected individuals had a normal physical, cognitive, and social development, and their interictal neurological examination was also normal. In this family only one patient (II:3) refused genetic testing.

\section{Genetic analysis}

Peripheral blood samples were collected from all family members willing to participate in this study. Genomic DNA was extracted using a standard salting-out method (Miller et al. 1988). To evaluate the involvement of the FHM2 locus in the Portuguese FHM families, microsatellite markers D1S2624, D1S2707 and D1S2844 were tested (data not shown). Oligonucleotide primer sequences were obtained from the Human Genome Database (GDB) (http:// www.gdb.org/). After DNA amplification, PCR products were detected by use of an automated sequencer (ABI 3700 DNA sequencer, Applied Biosystems, Foster City, CA, USA). All genotypes were analyzed and independently scored by M-JC and KRJV, using Genescan and Genotyper 2.1 software (Applied Biosystems). Haplotypes were constructed by evaluating the segregation and assuming a minimal number of recombinations.

For mutation analysis, PCR was performed for all 23 exons and flanking intronic regions of the ATP1A2 gene, using genomic DNA of patients I:2 and III: 1 from families 1 and 2, respectively, as a template. All PCR products were directly sequenced, using the Big Dye Terminator Ready Reaction Kit (Applied Biosystems) and an ABI 3730 sequencer apparatus (Applied Biosystems). For detection of the M731T mutation ( $\mathrm{T}>\mathrm{C}$, nt position 2,296; Ac nr NM_000702), standard PCR followed by digestion with restriction enzyme NcoI was performed, as described elsewhere (Vanmolkot et al. 2003) (data not shown). For detection of the T376M mutation $(\mathrm{C}>\mathrm{T}$, nt position 1,231 , Ac nr NM_000702), exons 9 and 10 were amplified by PCR, using primers "exon9-10F" (5'-GCCACGGTCTAGGGT AAGGT-3') and "exon9-10R" (5'-GCAAGAGGCTTTGG AGACAC- $3^{\prime}$ ), resulting in a 571-bp product. Carrier status for this mutation was evaluated by direct sequencing of the PCR products.

Functional analysis

Functional analysis of ATP1A2 mutation T376M was performed by survival assays. Human $\mathrm{Na}^{+}, \mathrm{K}^{+}$-ATPase $\alpha 2$ subunit cDNA was subcloned into a modified pCDNA3.1 


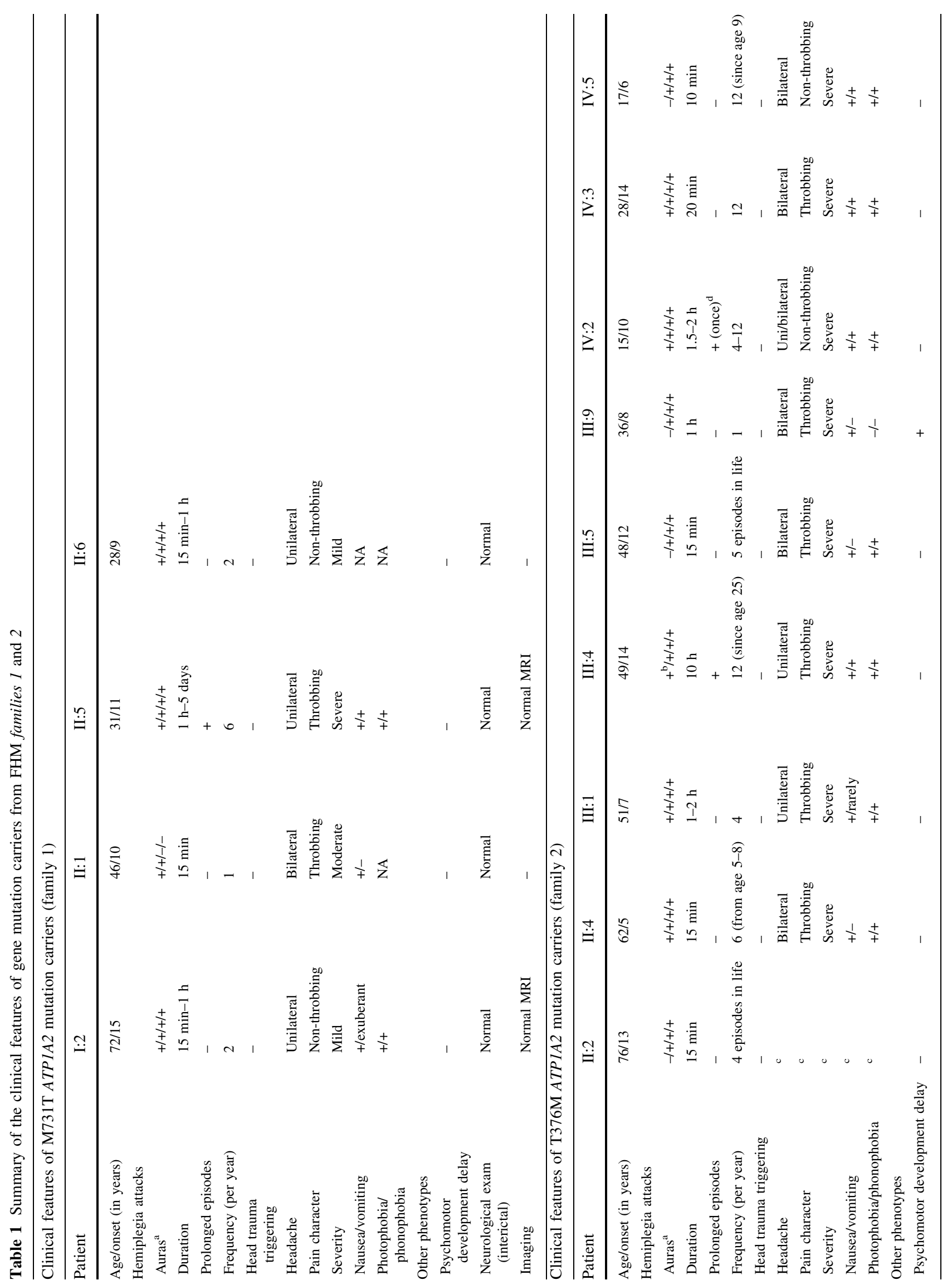




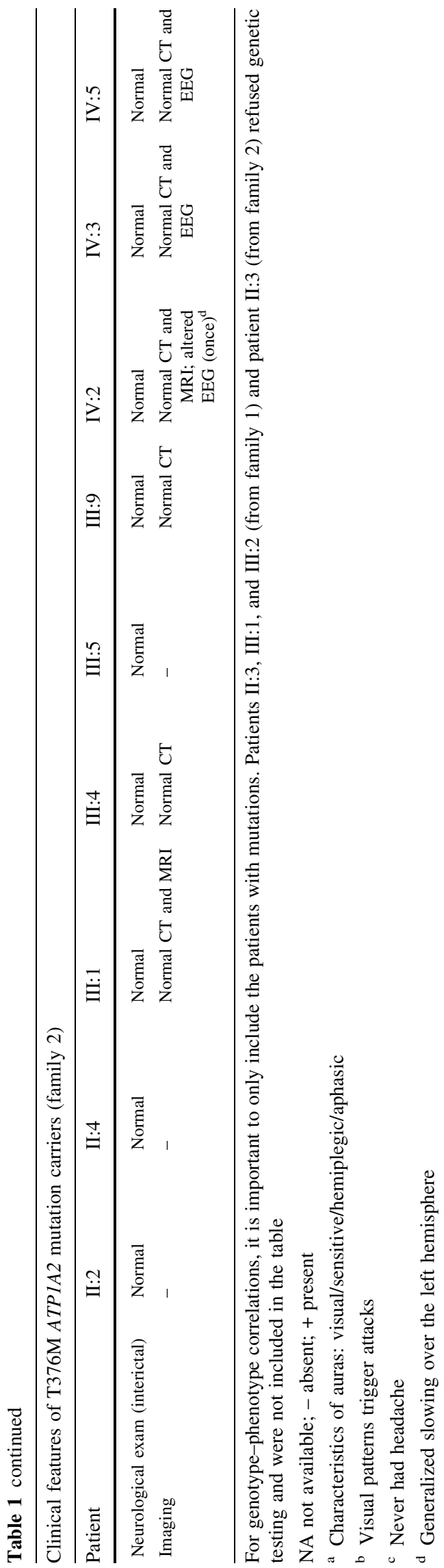

vector (Koenderink et al. 2005). To distinguish endogenous $\mathrm{Na}^{+}, \mathrm{K}^{+}$-ATPase activity from that of transfected $\mathrm{Na}^{+}, \mathrm{K}^{+}$ATPase, we used a cDNA encoding ouabain-resistant wildtype (ATP1A2-WT) (Price et al. 1990). Mutation T376M was introduced in the ouabain-resistant wild-type $\alpha 2$-subunit construct by site-directed mutagenesis (Quikchange; Stratagene, La Jolla, CA, USA). HeLa cells $\left(5 \times 10^{5}\right)$ were transfected with plasmid DNA of either ATP1A2-WT or ATP1A2-mutant (ATP1A2-T376M) using Lipofectamine 2000 Transfection Reagent (Invitrogen, Carlsbad, CA, USA). Two days after transfection, two-thirds of the cells were harvested for immunoblotting. In brief, proteins were resuspended in a mix of protease-inhibitor (Complete Mini, Roche, Basel, Switzerland) and DNaseI. Subsequently, Laemmli-loading buffer and $0.1 \mathrm{~mol} \mathrm{~L}^{-1}$ DTT were added and the samples were heated for $10 \mathrm{~min}$ at $65^{\circ} \mathrm{C}$. Next, equal amounts of protein as measured by the Bio-Rad protein assay (Bio-Rad Laboratories, Munich, Germany) were separated on $7.5 \%$ SDS-polyacrylamide gels for $40 \mathrm{~min}$ at $200 \mathrm{~V}$. Proteins were electroblotted to nitrocellulose membranes (Hybond, Amersham, Buckinghamshire, UK) and incubated overnight with the $\alpha 2$-subunit-specific polyclonal antibody HERED (Pressley 1992). The primary antibody was detected with goat-anti-rabbit horseradish peroxidase (HRP)-conjugated secondary antibody (Sigma, St Louis, MO, USA). Protein bands were visualized with Super Signal Substrate (Pierce Biotechnology, Rockford, IL, USA).

For the survival assay itself, the remaining one-third of the cells $\left(1.7 \times 10^{5}\right)$ was seeded on $10 \mathrm{~cm}$ Petri dishes and subsequently $1 \mu \mathrm{mol} \mathrm{L} \mathrm{L}^{-1}$ ouabain was added to the culture medium. After 5 days of ouabain challenge, colonies were stained with $1 \%$ methylene blue in $70 \%$ methanol, scanned and analyzed with Image Pro Plus (MediaCybernetics, Silverspring, MD, USA). In these assays, untransfected cells do not produce colonies. Each transfection was performed 7-15 times and the average values of visible colonies were calculated for each construct. The average number of colonies obtained with the wild-type construct was used as a reference (i.e. $100 \%$ cell survival). Next, the relative percentage of cell survival was calculated for the mutant construct. Statistical significance was determined using a Student's $t$ test $(P<0.05)$.

\section{Results}

In both Portuguese families the phenotype was pure FHM, although in some patients some variation in additional clinical features was observed, such as prolonged, atypical auras and abnormal behavior with learning difficulties. In both families, haplotypes were compatible with the involvement of the chromosome 1q23-linked FHM2 locus 
Fig. 2 Scheme of the $\mathrm{Na}^{+}, \mathrm{K}^{+}$ATPase $\alpha 2$ subunit, showing the location of all FHM2 recurrent mutations: gray-filled stars depict the mutations reported here; white-filled stars represent mutations previously reported in more than one family, namely R763H (Jurkat-Rott et al. 2004) and A606T (Riant et al. 2005). Inserts Electropherograms of heterozygous mutations resulting in substitutions M731T and T376M

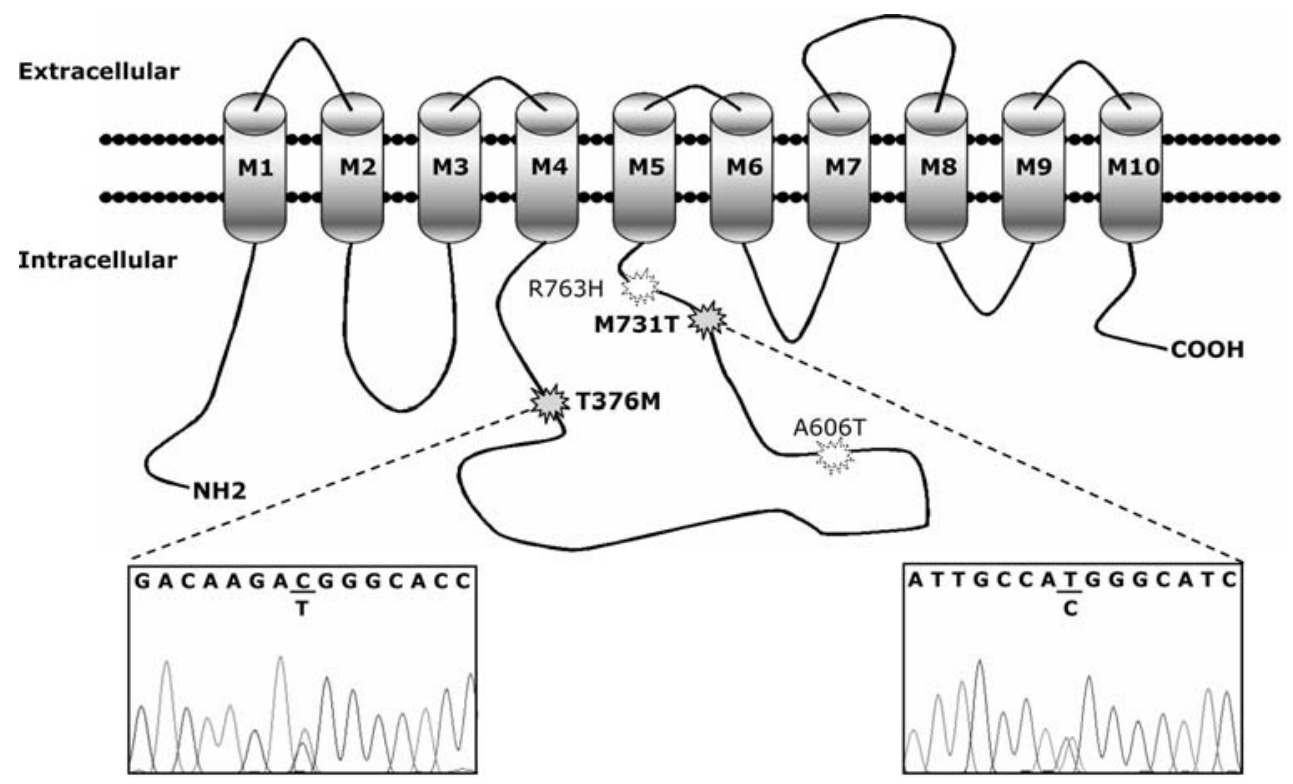

(data not shown). Mutation analysis of the ATP1A2 gene revealed missense mutations $\mathrm{M} 731 \mathrm{~T}$ and $\mathrm{T} 376 \mathrm{M}$ in families 1 and 2, respectively.

The M731T mutation in exon 16 (nt 2,296 T $>\mathrm{C}$ ) causes a substitution of a threonine for a methionine, at position 731 of the $\alpha 2$ subunit of the $\mathrm{Na}^{+}, \mathrm{K}^{+}$-ATPase pump (Fig. 2). The mutation co-segregated with FHM in all three mutation carriers for which DNA was available, and in an obligate carrier diagnosed with "non-motor auras" (Fig. 1a). The T376M mutation is located in exon 9 (nt $1,231, \mathrm{C}>\mathrm{T}$ ) and leads to a threonine for methionine change at position 376 of the pump protein (Fig. 2). This mutation co-segregated in all nine FHM patients of which DNA was available, and was also identified in one asymptomatic young girl (Fig. 1b).

Neither mutation was observed in a panel of 352 Portuguese control chromosomes.

Conservation of both amino acids $\mathrm{Met}^{731}$ and $\mathrm{Thr}^{376}$ was very high among several $\alpha$-subunits of the $\mathrm{P}_{2}$-type ATPase subfamily and within different species, as previously shown (Vanmolkot et al. 2003; Riant et al. 2005). Functional analyses of mutant M731T already revealed dysfunction of the $\mathrm{Na}^{+}, \mathrm{K}^{+}$pump (Capendeguy and Horisberger 2004; Segall et al. 2005). However, dysfunction of sodium-potassium pumps that contained the $\alpha 2$ subunit with the T376M mutation has not been reported before. Here functional consequences of ATP1A2 mutation $\mathrm{T} 376 \mathrm{M}$ were investigated using survival assays in HeLa cells. Survival assays test for the ability of mutant alleles to compensate for the loss of endogenous $\mathrm{Na}^{+}, \mathrm{K}^{+}$pump function (achieved by ouabain treatment). In the assay, transfected wild-type (ATP1A2-WT) and mutant (ATP1A2-T376M) $\mathrm{Na}^{+}, \mathrm{K}^{+}$-ATPase $\alpha 2$ subunits are ouabain-insensitive, because of mutations in the ouabainbinding site (Price et al. 1990). Western blot analysis showed that the wild-type and mutant constructs were expressed at comparable levels (Fig. 3a). In the survival assay, cells expressing the wild-type construct survived ouabain treatment (set as reference to $100 \%$ ). In contrast, ATP1A2 mutant T376M gave only very reduced level of survival $(<10 \%)$, indicating, for the first time, a clear functional consequence for this mutant (Fig. 3b).

\section{Discussion}

Here we describe two Portuguese families with pure FHM, presenting with mutations M731T and T376M in the $\mathrm{Na}^{+}, \mathrm{K}^{+}$-ATPase ATP1A2 gene and, for the first time, present meaningful genotype-phenotype correlations for this gene. Both mutations can be considered diseasecausing because they:

1 co-segregated with the affected phenotype in the respective families (with only one case of incomplete penetrance in family 1 (II:1) and in family 2 (IV:1));

2 were described in previous FHM studies (Vanmolkot et al. 2003; Riant et al. 2005);

3 were not found in a large Portuguese control panel;

4 affected highly conserved, important, amino acid residues in the $\alpha 2 \mathrm{Na}^{+}, \mathrm{K}^{+}$pump protein;

5 mutation M731T had already been shown to cause dysfunction of the $\mathrm{Na}^{+}, \mathrm{K}^{+}$pump (Capendeguy and Horisberger 2004; Segall et al. 2005); and

6 mutation T376M was shown here to result in dysfunctional $\mathrm{Na}^{+}, \mathrm{K}^{+}$pumps as shown by survival assays. 
a
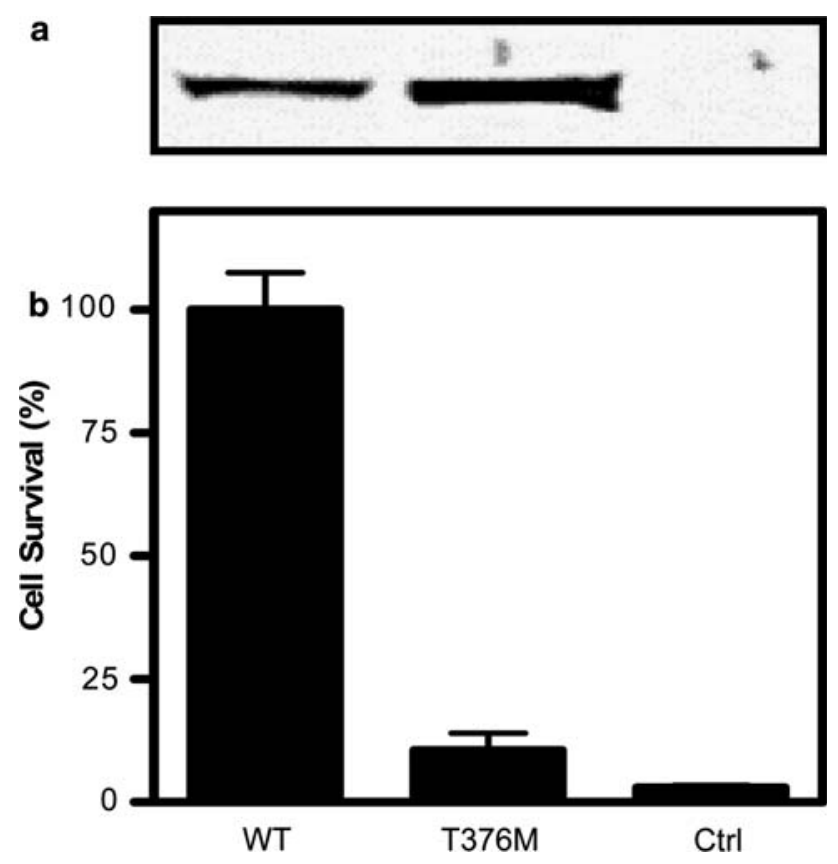

Fig. 3 Ouabain survival assay of ATP1A2 mutant T376M. a Western blot analysis of HeLa cells transfected with WT or mutant ATP1A2 cDNA. Detection of $\mathrm{Na}^{+}, \mathrm{K}^{+}$-ATPase $\alpha 2$-subunit protein was performed using a specific polyclonal antibody (anti-HERED). Specificity of the antibody is also shown from the absence of signal in the Ctrl lane (containing untransfected HeLa cells that express primarily the $\alpha 1$-subunit) b Ouabain sensitivity of cells transfected with either wild-type or mutant ATP1A2 cDNA. Bars represent cell survival after 5 days of ouabain treatment (error bars: SEM). Ctrl control; represents mock-transfected HeLa cells

Both mutations are located in the large M4-M5 cytoplasmic loop of the sodium-potassium pump subunit. $\mathrm{Met}^{731}$ is located in the conserved part of the domain P of the Rossman fold that is next to the phosphorylation site (Toyoshima et al. 2000). Interestingly, the pig kidney $\mathrm{Na}^{+}, \mathrm{K}^{+}$-ATPase homologous methionine is located in close proximity to a segment reported as essential for the overall folding and maturation of the pump (Jorgensen et al. 1998). $\mathrm{Thr}^{376}$ is located only two amino acids away from $\mathrm{Asp}^{374}$ that is equivalent to $\mathrm{Asp}^{351}$, a crucial amino acid in a phosphorylation site of $\mathrm{Ca}^{2+}$-ATPases (Toyoshima et al. 2000). Studies of yeast PMA1 $\mathrm{H}^{+}$-ATPase revealed that residues surrounding the equivalent aspartate residue $\mathrm{Asp}^{378}$ are critical for ATPase biogenesis, appropriate folding, and interaction with the secretory machinery (DeWitt et al. 1998). Functional consequences of mutation M731T, introduced in the human ATP1A2 cDNA, have been analyzed previously, revealing reduced catalytic turnover (Capendeguy and Horisberger 2004; Segall et al. 2005). The functional consequences of human mutation T376M have yet not been reported, but studies of yeast PMA1 $\mathrm{H}^{+}$-ATPase mutant T380A (e.g., the equivalent of human residue $\mathrm{Thr}^{376}$ ) revealed serious functional consequences as the mutant
ATPase protein was retained in the endoplasmatic reticulum and did not reach the plasma membrane in sufficient quantity (DeWitt et al. 1998).

Although recurrent mutations are rather common in FHM1, before this study, only three FHM2 mutations had been found in more than one family: T376M (Riant et al. 2005), A606T (Riant et al. 2005), and R763H (Jurkat-Rott et al. 2004). One important reason to identify recurrent mutations is that a larger number of mutation carriers allow better evaluation of the associated clinical phenotype (including variation in clinical features and associated symptoms). Secondly, recurrence of a mutation adds weight to the evidence that it is indeed the mutation that causes the disease phenotype-the mutation is present on different haplotypes.

Before this study, five carriers of mutation M731T and nine carriers of mutation T376M had been identified in three families (Vanmolkot et al. 2003; Riant et al. 2005). Four M731T mutation carriers in a Dutch family (Vanmolkot et al. 2003) and the three new Portuguese carriers in this study suffer from pure FHM, indicating that this mutation is clearly associated with this phenotype. Since haplotype analysis revealed different disease haplotypes for both families, the M731T is a recurrent mutation (data not shown). The three published T376M families originated from different countries (France, Italy, and Portugal) (Riant et al. 2005 and this study) and the mutation, is most probably recurrent, although no haplotyping data were reported. Ten additional $\mathrm{T} 376 \mathrm{M}$ mutation carriers are presented here, increasing the total number of mutation carriers to nineteen, allowing better genotype-phenotype correlations. The T376M mutation is associated with pure FHM in this large set of mutation carriers.

Recurrence of a mutation is more likely when the mutation is located in a $\mathrm{CpG}$ dinucleotide that is methylated on its cytosine, because it is more prone to deamination causing a $\mathrm{C}$ to $\mathrm{T}$ mutation event. Recurrent FHM1 mutations S218L, R583Q, T666M, and R1667W and FHM2 mutations $\mathrm{T} 376 \mathrm{M}$ and $\mathrm{R} 763 \mathrm{H}$ affect a $\mathrm{CpG}$ dinucleotide, and these mutations thus probably have occurred via this mechanism. Mutation M731T, now also a recurrent mutation, does not affect a $\mathrm{CpG}$ dinucleotide and occurred through a deamination-independent mutation event.

In conclusion, we demonstrated by considerably expanding the number of carriers of ATP1A2 mutations M731T and T376M that the phenotype associated with FHM2 mutations is homogenous (i.e. pure FHM). Of note, the clinical phenotype associated with ATP1A2 mutations seems more homogenous than reported for FHM1 mutations with a large number of mutation carriers. The fact that recurrence of FHM mutations was observed in our two Portuguese FHM families gives unique opportunities for genotype-phenotype correlations. In addition, this suggests 
that recurrent mutation sites in these FHM genes should be analyzed with priority when performing molecular diagnosis.

Acknowledgments We would like to thank Dr A. Levy Gomes for referring the proband of family 2 to us. We are particularly grateful to both Portuguese families for their participation and contribution for this study. The European Community provided financial support for this work, through a Marie-Curie grant for PhD students (M.-J.C, R.R.F.; contract no QLGA-CT-2000-60005), the "EUROHEAD" grant (LSHM-CT-2004-504837; R.R.F., M.D.F., A.M.J.M.vdM.), and Center of Medical System Biology (CMSB) established by The Netherlands Genomics Initiative/Netherlands Organisation for Scientific Research (NGI/NWO).

\section{References}

Alonso I, Barros J, Tuna A, Coelho J, Sequeiros J, Silveira I, Coutinho P (2003) Phenotypes of spinocerebellar ataxia type 6 and familial hemiplegic migraine caused by a unique CACNA1A missense mutation in patients from a large family. Arch Neurol 60:610-614

Ambrosini A, D’Onofrio M, Grieco GS, Di Mambro A, Montagna G, Fortini D, Nicoletti F, Nappi G, Sances G, Schoenen J, Buzzi MG, Santorelli FM, Pierelli F (2005) Familial basilar migraine associated with a new mutation in the ATP1A2 gene. Neurology 65:1826-1828

Bassi MT, Bresolin N, Tonelli A, Nazos K, Crippa F, Baschirotto C, Zucca C, Bersano A, Dolcetta D, Boneschi FM, Barone V, Casari G (2004) A novel mutation in the ATP1A2 gene causes alternating hemiplegia of childhood. J Med Genet 41:621-628

Battistini S, Stenirri S, Piatti M, Gelfi C, Righetti PG, Rocchi R, Giannini F, Battistini N, Guazzi GC, Ferrari M, Carrera P (1999) A new CACNA1A gene mutation in acetazolamide-responsive familial hemiplegic migraine and ataxia. Neurology 53:38-43

Capendeguy O, Horisberger JD (2004) Functional effects of $\mathrm{Na}+\mathrm{K}+-$ ATPase gene mutations. Neuromol Med 6:105-116

De Fusco M, Marconi R, Silvestri L, Atorino L, Rampoldi L, Morgante L, Ballabio A, Aridon P, Casari G (2003) Haploinsufficiency of ATP1A2 encoding the $\mathrm{Na}+\mathrm{K}+$ pump alpha2 subunit associated with familial hemiplegic migraine type 2 . Nat Genet 33:192-196

DeWitt ND, dos Santos CF, Allen KE, Slayman CW (1998) Phosphorylation region of the yeast plasma-membrane $\mathrm{H}+-$ ATPase. Role in protein folding and biogenesis. J Biol Chem 273:21744-21751

Dichgans M, Freilinger T, Eckstein G, Babini E, Lorenz-Depiereux B, Biskup S, Ferrari MD, Herzog J, van den Maagdenberg AM, Pusch M, Strom TM (2005) Mutation in the neuronal voltagegated sodium channel SCN1A in familial hemiplegic migraine. Lancet 366:371-377

Ducros A, Joutel A, Vahedi K, Cecillon M, Ferreira A, Bernard E, Verier A, Echenne B, Lopez de Munain A, Bousser MG, Tournier-Lasserve E (1997) Mapping of a second locus for familial hemiplegic migraine to $1 \mathrm{q} 21-\mathrm{q} 23$ and evidence of further heterogeneity. Ann Neurol 42:885-890

Ducros A, Denier C, Joutel A, Vahedi K, Michel A, Darcel F, Madigand M, Guerouaou D, Tison F, Julien J, Hirsch E, Chedru F, Bisgard C, Lucotte G, Despres P, Billard C, Barthez MA, Ponsot G, Bousser MG, Tournier-Lasserve E (1999) Recurrence of the T666M calcium channel CACNA1A gene mutation in familial hemiplegic migraine with progressive cerebellar ataxia. Am J Hum Genet 64:89-98
Ducros A, Denier C, Joutel A, Cecillon M, Lescoat C, Vahedi K, Darcel F, Vicaut E, Bousser MG, Tournier-Lasserve E (2001) The clinical spectrum of familial hemiplegic migraine associated with mutations in a neuronal calcium channel. $\mathrm{N}$ Engl $\mathrm{J}$ Med 345:17-24

Friend KL, Crimmins D, Phan TG, Sue CM, Colley A, Fung VS, Morris JG, Sutherland GR, Richards RI (1999) Detection of a novel missense mutation and second recurrent mutation in the CACNA1A gene in individuals with EA-2 and FHM. Hum Genet 105:261-265

Headache Classification Subcommittee of the International Headache Society (2004) The International Classification of Headache Disorders, 2nd edition. Cephalalgia 24(Suppl 1):9-160

Jorgensen PL, Nielsen JM, Rasmussen JH, Pedersen PA (1998) Structure-function relationships of E1-E2 transitions and cation binding in Na,K-pump protein. Biochim Biophys Acta 1365:6570

Jouvenceau A, Eunson LH, Spauschus A, Ramesh V, Zuberi SM, Kullmann DM, Hanna MG (2001) Human epilepsy associated with dysfunction of the brain P/Q-type calcium channel. Lancet 358:801-807

Jurkat-Rott K, Freilinger T, Dreier JP, Herzog J, Gobel H, Petzold GC, Montagna P, Gasser T, Lehmann-Horn F, Dichgans M (2004) Variability of familial hemiplegic migraine with novel A1A2 Na+/K+-ATPase variants. Neurology 62:1857-1861

Kaunisto MA, Harno H, Vanmolkot KR, Gargus JJ, Sun G, Hamalainen E, Liukkonen E, Kallela M, van den Maagdenberg AM, Frants RR, Farkkila M, Palotie A, Wessman M (2004) A novel missense ATP1A2 mutation in a Finnish family with familial hemiplegic migraine type 2. Neurogenetics 5:141-146

Koenderink JB, Zifarelli G, Qiu LY, Schwarz W, De Pont JJ, Bamberg E, Friedrich T (2005) Na,K-ATPase mutations in familial hemiplegic migraine lead to functional inactivation. Biochim Biophys Acta 1669:61-68

Kors EE, Haan J, Giffin NJ, Pazdera L, Schnittger C, Lennox GG, Terwindt GM, Vermeulen FL, Van den Maagdenberg AM, Frants RR, Ferrari MD (2003) Expanding the phenotypic spectrum of the CACNA1A gene T666M mutation: a description of 5 families with familial hemiplegic migraine. Arch Neurol 60:684-688

Miller SA, Dykes DD, Polesky HF (1988) A simple salting out procedure for extracting DNA from human nucleated cells. Nucleic Acids Res 16:1215

Ophoff RA, Terwindt GM, Vergouwe MN, van Eijk R, Oefner PJ, Hoffman SM, Lamerdin JE, Mohrenweiser HW, Bulman DE, Ferrari M, Haan J, Lindhout D, van Ommen GJ, Hofker MH, Ferrari MD, Frants RR (1996) Familial hemiplegic migraine and episodic ataxia type-2 are caused by mutations in the $\mathrm{Ca} 2+$ channel gene CACNL1A4. Cell 87:543-552

Pierelli F, Grieco GS, Pauri F, Pirro C, Fiermonte G, Ambrosini A, Costa A, Buzzi MG, Valoppi M, Caltagirone C, Nappi G, Santorelli FM (2006) A novel ATP1A2 mutation in a family with FHM type II. Cephalalgia 26:324-328

Pressley TA (1992) Phylogenetic conservation of isoform-specific regions within alpha-subunit of $\mathrm{Na}(+)-\mathrm{K}(+)$-ATPase. Am J Physiol 262:C743-C751

Price EM, Rice DA, Lingrel JB (1990) Structure-function studies of $\mathrm{Na}, \mathrm{K}-\mathrm{ATPase}$. Site-directed mutagenesis of the border residues from the $\mathrm{H} 1-\mathrm{H} 2$ extracellular domain of the alpha subunit. J Biol Chem 265:6638-6641

Riant F, De Fusco M, Aridon P, Ducros A, Ploton C, Marchelli F, Maciazek J, Bousser MG, Casari G, Tournier-Lasserve E (2005) ATP1A2 mutations in 11 families with familial hemiplegic migraine. Hum Mutat 26:281-287

Segall L, Mezzetti A, Scanzano R, Gargus JJ, Purisima E, Blostein R (2005) Alterations in the alpha2 isoform of Na,K-ATPase 
associated with familial hemiplegic migraine type 2. Proc Natl Acad Sci USA 102:11106-11111

Spadaro M, Ursu S, Lehmann-Horn F, Liana V, Giovanni A, Paola G, Frontali M, Jurkat-Rott K (2004) A G301R Na+/K+-ATPase mutation causes familial hemiplegic migraine type 2 with cerebellar signs. Neurogenetics 5:177-185

Swoboda KJ, Kanavakis E, Xaidara A, Johnson JE, Leppert MF, Schlesinger-Massart MB, Ptacek LJ, Silver K, Youroukos S (2004) Alternating hemiplegia of childhood or familial hemiplegic migraine? A novel ATP1A2 mutation. Ann Neurol 55:884-887

Terwindt G, Kors E, Haan J, Vermeulen F, Van den Maagdenberg A, Frants R, Ferrari M (2002) Mutation analysis of the CACNA1A calcium channel subunit gene in 27 patients with sporadic hemiplegic migraine. Arch Neurol 59:1016-1018
Toyoshima C, Nakasako M, Nomura H, Ogawa H (2000) Crystal structure of the calcium pump of sarcoplasmic reticulum at $2.6 \mathrm{~A}$ resolution. Nature 405:647-655

Vanmolkot KR, Kors EE, Hottenga JJ, Terwindt GM, Haan J, Hoefnagels WA, Black DF, Sandkuijl LA, Frants RR, Ferrari MD, van den Maagdenberg AM (2003) Novel mutations in the $\mathrm{Na}+, \mathrm{K}+$-ATPase pump gene ATP1A2 associated with familial hemiplegic migraine and benign familial infantile convulsions. Ann Neurol 54:360-366

Vanmolkot KR, Stroink H, Koenderink JB, Kors EE, van den Heuvel JJ, van den Boogerd EH, Stam AH, Haan J, De Vries BB, Terwindt GM, Frants RR, Ferrari MD, van den Maagdenberg AM (2006) Severe episodic neurological deficits and permanent mental retardation in a child with a novel FHM2 ATP1A2 mutation. Ann Neurol 59:310-314 